\title{
Accelerated growth of Kappaphycus alvarezii using Sargassum aquifolium extract and its anatomical characteristics
}

\author{
NUNIK COKROWATI ${ }^{1,2, \vartheta}$, YENNY RISJANI ${ }^{1, \nu}$, MUHAMAD FIRDAUS $^{1}$, SRI ANDAYANI $^{1}$ \\ ${ }^{1}$ Graduate Program, Faculty of Fisheries and Marine Sciences, Universitas Brawijaya. Jl. Veteran, Malang 65145, East Java, Indonesia. \\ Tel.: +62-341-553512, `email: nunikcokrowati@unram.ac.id; nunikcokrowati@ student.ub.ac.id, w risjani@ub.ac.id \\ ${ }^{2}$ Aquaculture Program, Faculty of Agriculture, Universitas Mataram. Jl. Majapahit No. 67, Mataram 83125, West Nusa Tenggara, Indonesia
}

Manuscript received: 17 September 2021. Revision accepted: 30 October 2021.

\begin{abstract}
Cokrowati N, Risjani Y, Firdaus M, Andayani S. 2021. Accelerated growth of Kappaphycus alvarezii using Sargassum aquifolium extract and its anatomical characteristics. Biodiversitas 22: 5195-5202. Cultivation of Kappaphycus alvarezii seaweed has been carried out in Ekas Bay of Jerowaru Sub-district, East Lombok, West Nusa Tenggara, Indonesia but its production has decreased in the last three years due to its slow growth. In 2014, seaweed production was 1,882,875.50 tons and in 2017 it was $1,037,000$ tons. Efforts are needed to increase growth by providing growth triggers from marine natural ingredients, namely Sargassum aquifolium. These brown algae can be found in the waters of Ekas Bay, the numbers are abundant and untapped. The purpose of this study was to analyze the growth of $K$. alvarezii given $S$. aquifolium extract. This research was conducted in the waters of Ekas Bay. The method used is experimental. The experimental design used was a completely randomized design with different treatments of $K$. alvarezii soaking time using $S$. aquifolium extract. The results showed that the growth of $K$. alvarezii given $S$. aquifolium extract increased and was significantly different between treatments. The highest absolute weight was $479 \mathrm{~g}$ in treatment A (soaking for 2 hours) and the low est absolute weight was $181.25 \mathrm{~g}$ in treatment $\mathrm{K}$ (control). The highest growth rate occurred on the 18th day, namely $9.24 \%$ and the lowest was in the $\mathrm{K}$ treatment (control) which was $1.3 \%$.
\end{abstract}

Keywords: Brown algae, extracts, growth, macroalgae, phytohormones

\section{INTRODUCTION}

Kappaphycus alvarezii is a carrageenan-producing red alga that is spread in the islands of Indonesia as well as in other tropical countries such as Malaysia, the Philippines, China and countries in Latin America. There are several varieties in Asia, while in Indonesia these species are commonly found are brown and green morphotypes that have certain genetic characteristics (Risjani and Abidin 2020).

K. alvarezii cultivation has been carried out in Indonesia, including on the island of Lombok, West Nusa Tenggara Province and has become the livelihood of local communities (Rochester et al. 2016; Simatupang et al. 2021). West Nusa Tenggara Province seaweed production data (2020) explains that $K$. alvarezii production on Lombok Island tends to decrease. In 2017 the total production was $240,968.7$ tons; in 2018 it was 228,499 tons, and in 2019 it was 212,928.76 tons (DKP NTB, 2019). The study of the causes of the decline in seaweed production on the island of Lombok has not been carried out. The causes of the decline in production include the low quality of the seeds used (the seeds used are the results of previous plantings), limited availability of seeds, changes in weather, and shifts in the livelihoods of cultivators as lobster seed catchers. The cause of the decline in production that can be improved is the quality of seeds to increase growth. Seaweed growth occurs because seaweed carries out the process of respiration and photosynthesis. Kasim et al. (2017) and Aris et al. (2021) explained that the biological parameters that affect the growth of seaweed are age, phenotype, genotype, reproductive conditions, nutrition, and environmental conditions. Nitrogen limitation can cause red algae to catalyze some phycobiliproteins, thereby reducing their ability to capture light.

Currently, efforts are needed to increase growth by providing growth-promoting substances from marine natural materials such as Ulva, Padina and Sargassum (Garcia et al. 2020). Khan et al. (2009) and Basmal et al. (2019) mention that Sargassum is used as a biostimulant for plant growth because it contains components of macronutrients, micronutrients, amino acids, vitamins, cytokinins and auxins. Sargassum sp. can be used as a liquid fertilizer to increase the growth of crops. Mahmoud et al. (2019) stated that Sargassum has bioactive components and can be used as a biostimulant for organic crops. Wouthuyzen et al. (2016) explained that Sargassum could be found in the waters of North Sulawesi. This brown alga is also found in the waters of Ekas Bay, East Lombok, West Nusa Tenggara and is abundant and untapped. Sargassum aquifolium contains carbohydrates (59.51\%), fat (8.41\%), Ca (3.34\%), Fe (0.12\%), P (0.18\%) $\mathrm{Fe}(0.12 \%), \mathrm{Ca}(3.34 \%)$, water $(12.79 \%)$, ash $(12.79 \%), \mathrm{N}$ (7.22\%) (Mageswaran and Sivasubramanian 1984; Cokrowati 2019; Liu et al. 2020). The components present in $S$. aquifolium have the potential as phytohormones that can be used as growth triggers in $K$. alvarezii.

In general, seaweed has some phytohormones which have been detected by an RP-HPLC-PDA (Gorka et al. 
2017). Like in higher plants, marine algae growth and development are controlled by a hormonal regulatory system (Kiseleva et al. 2012). Various concentration of auxin phytohormone has been applied in marine microalgae (Yu et al. 2020). Meanwhile, Sargassum extract has been used as a phytohormone for tomato plants (Sasikala, et al. 2016; Khedia et al. 2020). The purpose of this study was to determine the growth of $K$. alvarezii given S. aquifolium extract.

\section{MATERIALS AND METHODS}

\section{Study area}

Exploration activities for $S$. aquifolium and $K$. alvarezii cultivation were carried out in the waters of Ekas Bay of Ekas Buana Village, Jerowaru Sub-district, East Lombok District, West Nusa Tenggara Province, Indonesia. The research location is as shown in the picture.

The cultivation of $K$. alvarezii was carried out using the floating raft method. The raft is square, made of bamboo with a raft size of $6 \mathrm{~m} \times 6 \mathrm{~m}$. The number of ropes used is 20 ropes, each with a length of $6 \mathrm{~m}$. Ropes are tied to bamboo rafts, the distance between ropes is $30 \mathrm{~cm}$. $K$. alvarezii is grown by tying it to a rope. In one rope, there are ten clumps of $K$. alvarezii, a total of 200 clumps. At each corner of the raft, ropes and anchors are attached to the bottom of the water. On each rope, given three buoys with a distance of $1.5 \mathrm{~m}$ between each buoy. Floating raft design and research treatment as shown in Figure 2.
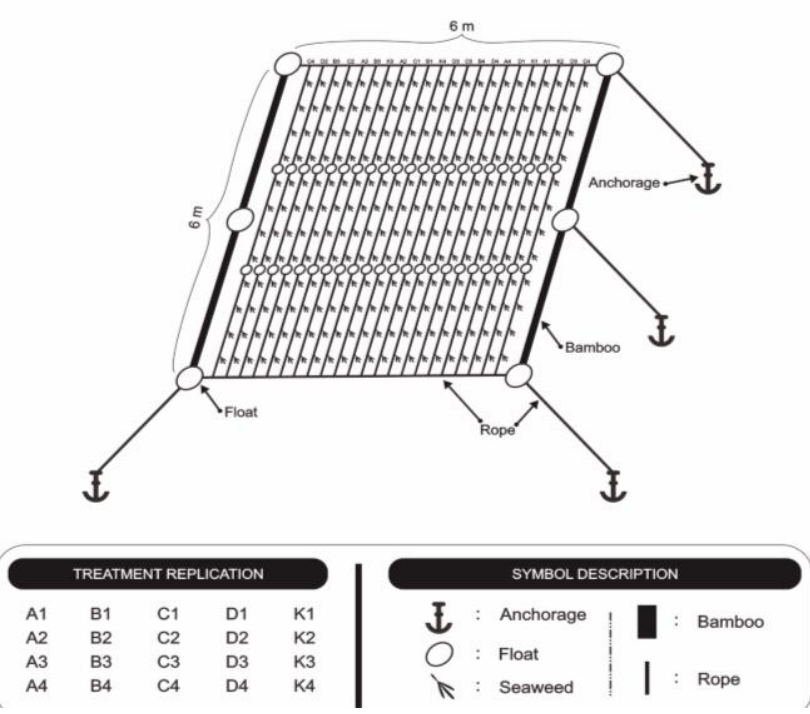

Figure 2. Floating raft design and research treatment

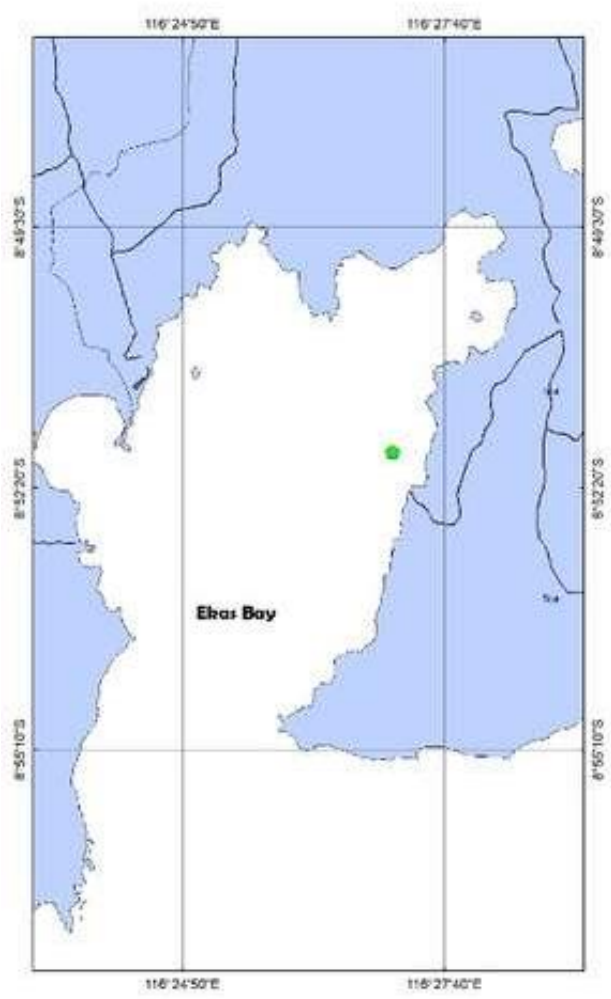

Figure 1. Research Location, Ekas Bay, Lombok Timur, Nusa Tenggara Barat; 850'27"S $116^{\circ} 27^{\prime 2} 24^{\prime \prime} \mathrm{E}$ 


\section{Procedures}

Extraction of Sargassum aquifolium

Sargassum aquifolium extract given to Kappahycus alvarezii is a crude extract with water as a solvent. The extract is made by mashing fresh $S$. aquifolium by grinding it until smooth. The mashed $S$. aquifolium was then added with seawater in a ratio of $1: 1$. The concentrated extract was then filtered and added with seawater up to a concentration of $5 \%$. The extract is ready to use and given by immersing $K$. alvarezii seeds in the extract.

The growth-promoting factor of $S$. aquifolium was studied by first making a crude extract using $99 \%$ methanol as solvent. Fresh S. aquifolium was washed with fresh water and then weighed using an analytical balance of 30 grams. The sample was put into a blender and $30 \mathrm{ml}$ of methanol was added and then blended until smooth. The extract was then filtered using filter paper and accommodated in a test tube. The extract was taken as much as $5 \mathrm{ml}$ using a syringe and filtered again using a sterile micro filter and then accommodated in a tube. The extract was diluted to a concentration of $1000 \mathrm{ppm}$ by taking $2 \mathrm{ml}$ of methanol and pouring it into a tube then adding $2 \mu \mathrm{ml}$ of $S$. aquifolium extract. The extract was ready to be injected into the HPLC machine for characterization of auxin, cytokinin, and gibberillin. Likewise, the method used to prepare samples of $K$. alvarezii extract to be analyzed for auxin, cytokinin and gibberillin.

\section{Analysis of Sargassum aquifolium extract}

Analysis was carried out using HPLC Shimaddzu LC10 AT VP, equipped with pump model LC-10AT, UV-Vis detector SPD-10AT, Rheodyne injector equipped with $20 \mathrm{~L}$ loop and automatic injector SIL-10AT. Hypersil BDS C-18 columns ( $4.6 \times 250 \mathrm{~mm}, 5 \mu \mathrm{m}$ in size) with C-18 shielding columns were used. Elution was carried out with a gradient solvent system with a flow rate of $1 \mathrm{~mL}$ min-1 at ambient temperature $\left(25-28{ }^{\circ} \mathrm{C}\right)$. The mobile phase consisted of $0.1 \% \mathrm{v} / \mathrm{v}$ methanol (solvent A) and water (solvent B). The mobile phase was prepared daily, filtered through $0.45 \mathrm{~m}$ and sonicated before use. The total running time is 15 minutes. The sample injection volume was $20 \mu \mathrm{L}$ while the UV-Vis detector wavelength was set at $254 \mathrm{~nm}$ (Marimuthu et al. 2012).

\section{Soaking Kappaphycus alvarezii using Sargassum} aquifolium extract

Sargassum aquifolium extract as a growth regulator was applied to the cultivated $K$. alvarezii. Kappaphycus. alvarezii seedlings were immersed in a 5\% concentration of $S$. aquifolium extract. The experimental design used was a completely randomized design. The treatments used were five treatments and four times the number of ris ropes. In this study, growth regulators were tested with different soaking time treatments, namely: (i) Treatment A : two hours (120 minutes), (ii) Treatment B : 1.5 hours (90 minutes), (iii) Treatment $\mathrm{C}$ : one hour (60 minutes), (iv) Treatment D : 0.5 hours (30 minutes), (v) Treatment K : Control (without immersion).

\section{Growth observation}

Growth observations were carried out every nine days, by weighing samples of the tagged thallus clumps in each treatment. The seaweed clumps from each experimental rope were measured for thallus weighed. Clumps that have been measured and weighed are replanted with tagging to be weighed again in the next nine days. The weighing was done every nine days to avoid stress on K. alvarezii. Absolute weight was calculated using the formula of Dawes et al. (1994).

$$
\Delta W=W t-W o
$$

Where:

$\Delta \mathrm{W}$ : Absolute Growth (g)

$\mathrm{Wt}$ : Average weight of seaweed at the end of the experiment $(\mathrm{g})$

Wo : Average weight of seaweed at the beginning of the experiment $(\mathrm{g})$

Daily growth rate data is calculated using the formula (Ohno' et al. 1994):

$$
\% \text { Daily Growth Rate }=100 \ln (w f / w 0) t-1
$$

Where:

wf : final fresh weight (grams)

W : initial fresh weight (grams)

$\mathrm{t} \quad$ : time interval (days)

\section{Data analysis}

The data from the analysis of growth-promoting factors were tabulated and analyzed descriptively. The growth data of $K$. alvarezii was analyzed statistically, then processed using Microsoft Excel and presented in graphical form.

\section{RESULTS AND DISCUSSION}

\section{Growth promoting factor in Sargassum aquifolium}

The results of the Growth-Promoting Factor analysis on $S$. aquifolium extract showed that the auxin content was $401.89 \mathrm{ppm}$ and gibberellin was $0.89 \mathrm{ppm}$. Cytokinins are thought to be so small that they are not detectable. Figure 1 is a chromatogram of $S$. aquifolium.

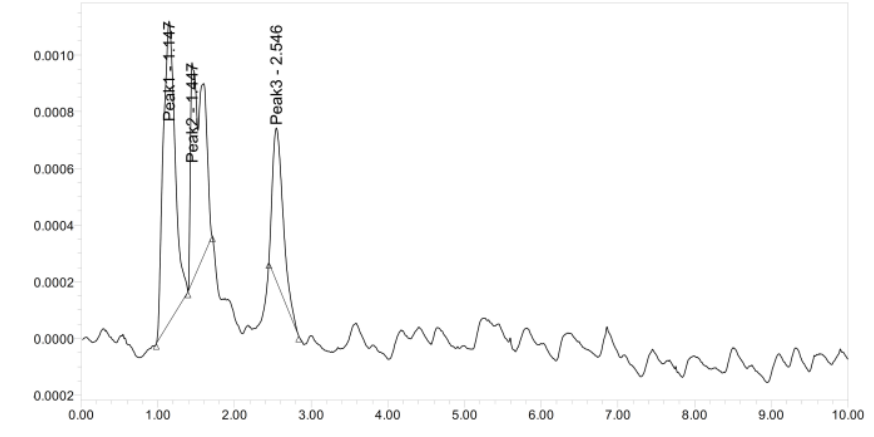

Figure 3. Chromatogram of Sargassum aquifolium 
Growth Promoting Factors in S. aquifolium detected were auxin and gibberellin. Auxin is found in leaves and a mixture of all parts of the $S$. aquifolium plant with a range of $280.11 \mathrm{ppm}-401.89 \mathrm{ppm}$. The auxin detected in this study was classified as greater than the results of previous studies on different types of Sargassum. However, the gibberellin in S. aquifolium was lower than that detected in other types of Sargassum. Basmal et al. (2015) mentioned the results of their analysis that Sargassum liquid fertilizer contains auxin 117.36-127.48 ppm, fibre line 121.66$131.11 \mathrm{ppm}$ and cytokinins $59.37-68.77 \mathrm{ppm}$. Zhang et al. (1991) explained the results of Sargassum cytokinin analysis that detected isopentenyl adenosine compounds as much as 0.9 g.Kg-1. Vijayanand et al. (2014) explained that Sargasaum weight detected $2.5 \mathrm{mg} / \mathrm{L}$ auxins, $5.5 \mathrm{mg} / \mathrm{L}$ cytokinins and $2.8 \mathrm{mg} / \mathrm{L}$ gibberilin. $\mathrm{Li}$ et al. (2016) explained that the phytohormones Sargassum horneri were distributed entirely in plant parts, namely $5066.67 \mathrm{ng} / \mathrm{g}$ (wet weight). Phytohormones in Sargassum fusiforme were detected as much as $4041,431 \mathrm{ng} / \mathrm{g}$ (Li et al. 2014).

Auxin plays a role in the process of cell metabolism so that it can increase growth and increase vegetative growth (Mahmoud et al. 2019; Sasikala 2016). Ljung et al. (2005) and Pacholczak et al. (2016) explained that auxin has an important role in root development, initiating root emergence, root apical meristem pattern and root elongation. In this study, the auxin of $S$. aquifolium when given to $K$. alvarezii as an endogenous auxin could trigger the formation of thallus branching in $K$. alvarezii. The formation of the thallus will be more with the addition of auxin, in addition to the auxin produced in the thallus of $K$. alvarezii itself. The growth of $K$. alvarezii was not only in the form of an increase in talus weight and length but also an increase in talus branching.

Panda et al. (2012) explained that brown algae contain gibberellins and can be used as fertilizer for plants. Gibberellin in the results of this study was detected as much as $0.89 \mathrm{ppm}-5.91 \mathrm{ppm}$. Gibberellin in S. aquifolium plays a role in growth in the form of stem elongation and leaf and fruit enlargement. Gao et al. (2017); Zein (2016) explained that gibberellins modulate plant growth and development. Extension and enlargement of organs. Giberilin promotes the activity of hydrolytic enzymes in the physiological process of development. Giberilin plays a role in the hydrolysis of starch, fructan and sucrose into glucose and fructose molecules. Based on this, $S$. aquifolium extract if given to $K$. alvarezii is thought to increase the growth and development of the thallus and its carrageenan content.

\section{Growth of Kappaphycus alvarezii \\ Absolute weight}

The absolute weight of $K$. alvarezii after 45 days of rearing can be seen in Figure 2. The highest final weight of harvest was $479 \mathrm{~g}$ in treatment A (2 hours) and the lowest weight was $181.25 \mathrm{~g}$ in treatment $\mathrm{K}$ (control). The absolute weight of $K$. alvarezii can be seen in Figure 4.

The absolute weight of $K$. alvarezii continued to increase from the beginning of cultivation until the 36th day. After the 36th day to the 45th day, the absolute weight begins to decrease and tends to harvest. Optimum weight is achieved on the 45th day, and at that age, harvesting should be carried out. If the thallus is too heavy, it will break and drift or fall to the bottom of the water.

The absolute maximum weight in this study produced by $K$. alvarezii was $479 \mathrm{~g}$ in treatment $\mathrm{A}$ (2 hours). Treatment A, which was soaking for 2 hours, was thought to be the optimum time for the thallus to absorb $S$. aquifolium extract. So that the auxins, cytokinins, and gibberellins that can be absorbed by the thallus can support optimal growth. The absolute weight of the S.aquifolium extract soaking treatment for 2 hours in this study was the optimal time to produce high absolute growth. Talus $K$. alvarezii has limited ability to absorb the given S.aquifolium extract. The cell will burst if too much fluid gets into it. Growth Promoting Factor present in S.aquifolium extract can trigger the absorption of nutrients in $K$. alvarezii tissue so that it can increase resistance to pressure from environmental conditions. So that the energy produced by $K$. alvarezii is allocated more for growth in the form of absolute weight gain. Cole et al. (1992) explained that growth is a morphological change that can be measured based on the increase in weight and length in a certain time. The growth that occurs in $\mathrm{K}$. alvarezii is not localized at one point and is spread throughout the thallus. The multiplication of somatic cells occurs randomly throughout the thallus.

The absorption of S.aquifolium extract by $K$. alvarezii through the process of diffusion of water molecules. The direction of the diffusion movement is to a place where there is a shortage of molecules, or to a place of low concentration. When a molecule diffuses through the pores, it is called osmosis. The absorption occurred when $K$. alvarezii was immersed in S.aquifolium solution, and optimally occurred at 2 hours of immersion in this study. Auxin in the extract of $S$. aquifolium was absorbed by entering through the surface of the thallus and into the cells of $K$. alvarezii. Kurniati et al. (2019) explained that auxin plays a role in promoting cell elongation, so that thallus growth occurs in the form of an increase in thallus length. So there is also an increase in talus weight. Khan et al. (2009); Zwack et al. (2013) explained that the administration of exogenous phytohormones can trigger the production of endogenous phytohormones in plants. Phytohormones owned by plants can stimulate the absorption of nutrients in plant tissues, thereby increasing resistance to environmental stress. The mechanism is through the process of breaking down protein and chlorophyll. The results of the decomposition are then distributed throughout the plant tissue. These phytohormones also play a role in the synthesis of chlorophyll, metabolism and use of water in the plant body.

The gibberellin in the extract of $S$. aquifolium was absorbed by the surface of the thallus of $K$. alvarezii and entered the cells. Giberilin triggers cell division in the thallus and triggers the activity of amylase and proteinase enzymes that work for germination in this case the increase in thallus branching. Agarwal et al. (2021) explained that brown algae extract increases plant resistance to environmental stress through the mechanism of regulating 
antioxidant pathways. These settings are in response to abiotic environmental stresses such as salinity, changes in water temperature. Abiotic stress in the form of bacteria, viruses and fungi. Brown algae extract can increase the activity of the enzyme catalase which works to respond to stress conditions.

\section{Daily growth rate}

The daily growth rate of $K$. alvarezii describes the percentage of weight gain that occurs per day during the cultivation period. The daily growth rate of $K$. alvarezii in this study can be seen in Figure 3.

The growth rate of $K$. alvarezii in Figure 3 explains that $K$. Alvarezii did maximum growth from the beginning of cultivation until the 18 th day of cultivation. K. Alvarezii in treatment A ( 2 hours) experienced the highest growth rate on day 18 , namely $9.2 \%$. After the 18 th day, the growth rate of $K$. alvarezii in all treatments decreased until the harvesting age was 45 days. The lowest growth rate on day 45 occurred in treatment $\mathrm{K}$ (control), which was $0.7 \%$.

The daily growth rate continued to increase on the 9th to the 27th day of cultivation, which was more than $3 \%$. The results of research by Kasim et al. (2019), Harapan et al. (2019) and Nadlir et al. (2019) stated that the optimal and economically profitable growth rate of $K$. alvarezii is more than $3 \%$. In this study, the optimal growth rate occurred on the 18th day, during the planting period cell growth in the thallus was supported by the given S.aquifolium extract. So that the maximum growth rate occurs. The results of this study on the 36th day to the 45th day the daily growth rate of $K$. alvarezii in each treatment tended to decrease from $2 \%$ to $1 \%$. On the 36 th to 45 th day of cultivation, the growth of cells was slower because $K$. alvarezii was getting older.

The daily growth rate of $K$. alvarezii per time can be described by the value of the specific growth rate. The

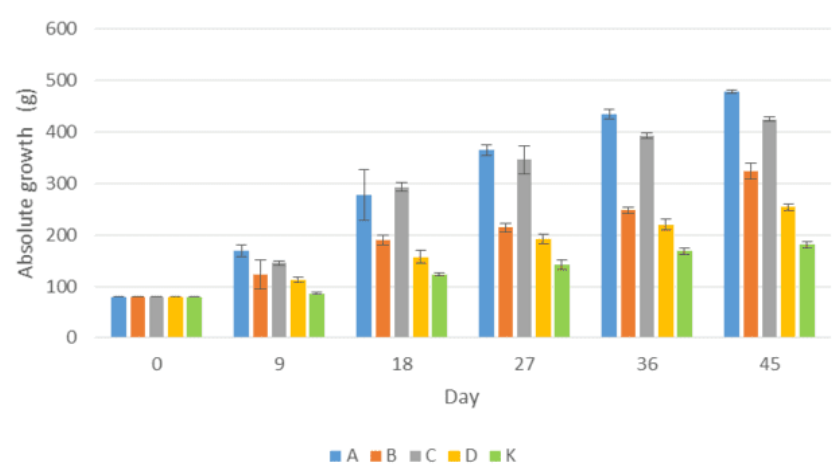

Figure 4. Absolute growth in thallus weight (gram) of Kappaphycus alvarezii based on the different treatments. A: 2 Hours; B: 1.5 Hours; C: 1 Hour; D: 0.5 Hours; K: Control specific growth rate is the ratio of the initial weight of seaweed to the final weight of seaweed each day. Factors that affect the growth of $K$. alvarezii consist of internal factors and external factors. Internal factors are type, talus part and age. Xiao et al. (2019) explained that the external factors were the physical, biological and chemical conditions of the waters. Physical conditions include the movement of water at the cultivation site in the form of currents. The movement of water can homogenize the water mass so that nutrients are evenly distributed and there is no accumulation of dirt attached to the thallus. Seaweed growth is also influenced by seasons. The results of research by Nursidi et al. (2017) explained that the optimal growth of $K$. alvarezii occurred in the rainy season because the water conditions were in the optimal range required by seaweed. In the dry season, the water conditions are not in optimal conditions for seaweed growth so that it can reduce the daily growth rate.

\section{Thallus cross section}

The immersion treatment of $S$. aquifolium extract had an effect on the state of $K$. alvarezii cells as shown in the image below. K. alvarezii cells in each treatment and each increase in cultivation time, looked healthy. Maulani et al. (2017) explained that a healthy network of cell components is clearly visible between the epidermis, outer cortex, and inner cortex. In healthy conditions, the shape of the cell, i.e. the distance between the cells, is still close. Tri (2002) explained that the cells are getting smaller in size towards the edge of the thallus. These outer cells are identical to the cells of the thallus tip (apical), where it is said that the apical portion consists of cells that are actively growing. Figure 6. is a cross-section of the thallus of $K$. alvarezii, which has been treated and cultivated for 45 days.

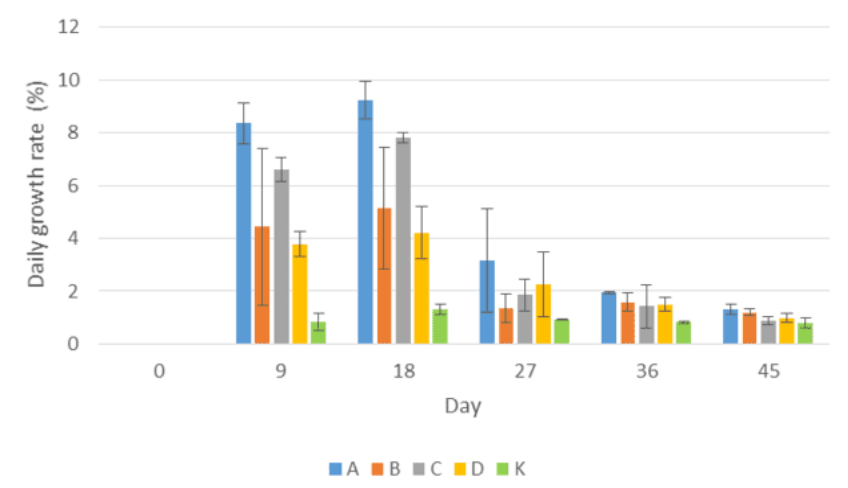

Figure 3. The daily growth rate in thallus weight (grams) of Kappaphycus alvarezii is based on the different treatments. A: 2 Hours; B: 1.5 Hours; C: 1 Hour; D: 0.5 Hours; K: Control 
Day-0

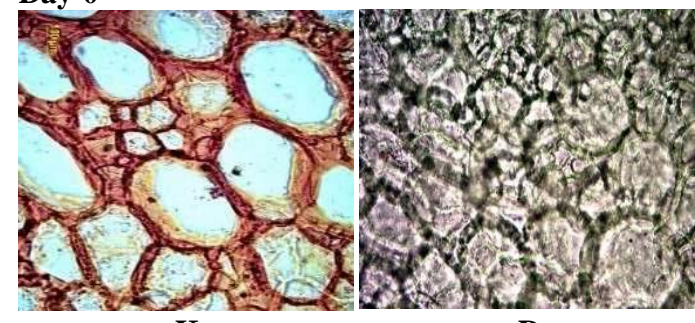

$\mathbf{K}$

Day-9

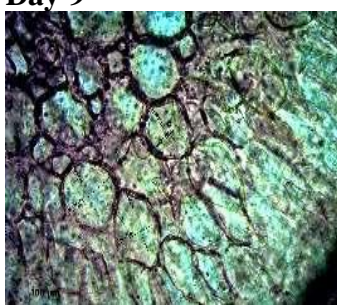

$\mathbf{K}$

Day-18

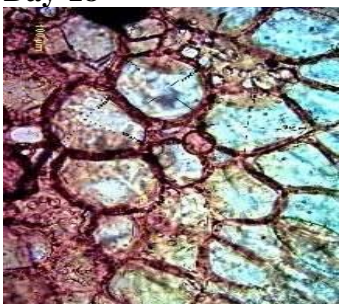

$\mathbf{K}$

Day-27

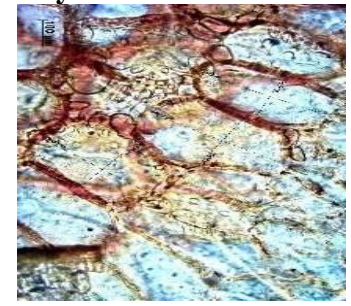

$\mathbf{K}$

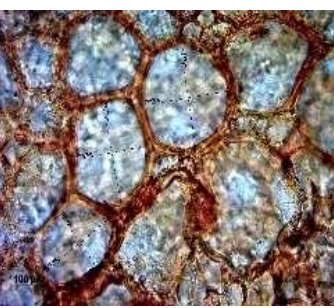

D

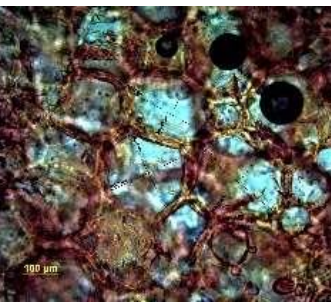

D

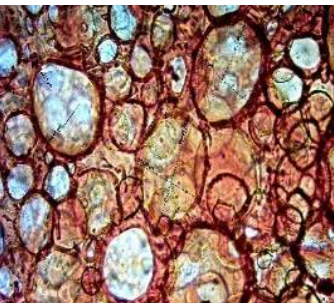

D

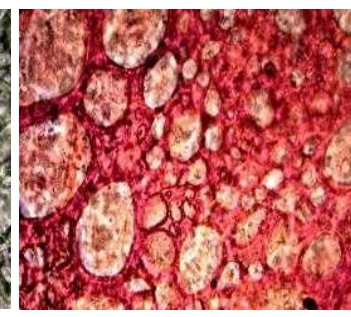

C

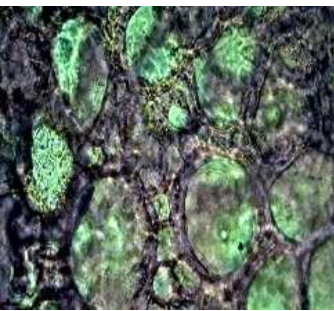

B

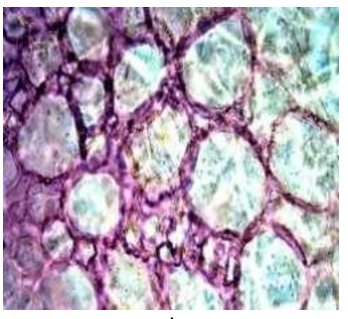

A

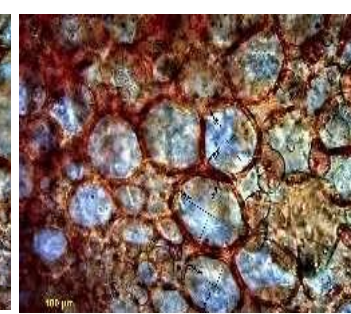

C

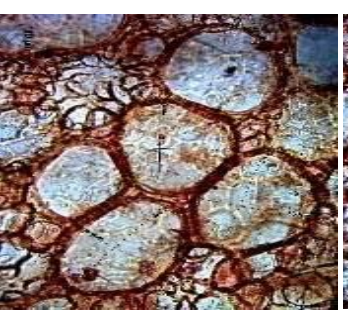

B

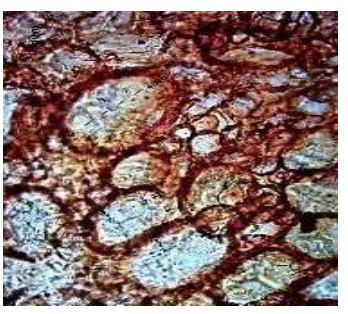

A

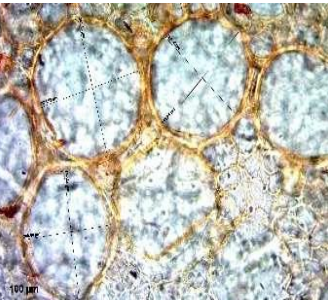

C

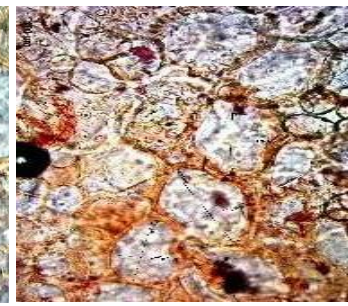

B

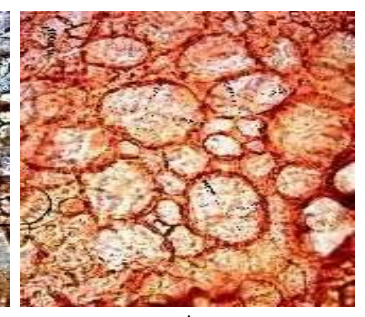

A

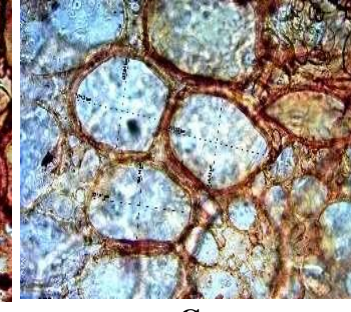

C

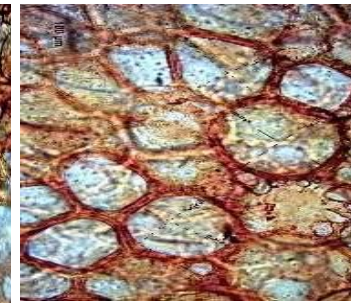

B

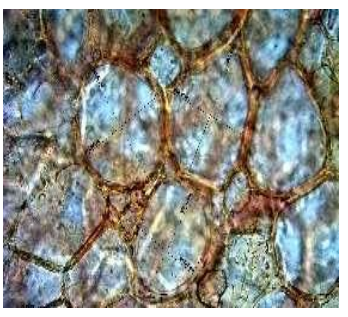

A

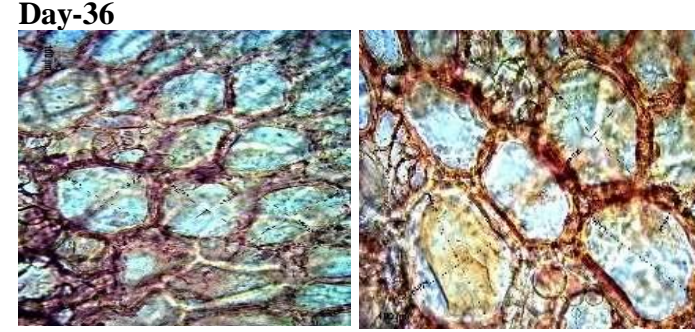

K

D

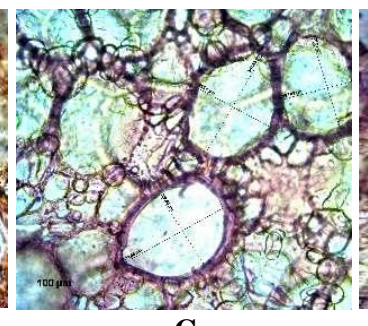

C

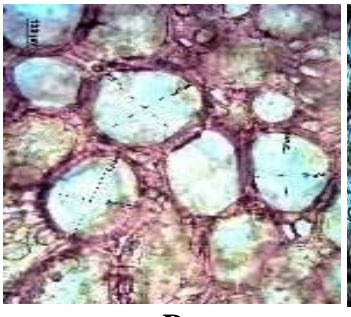

B

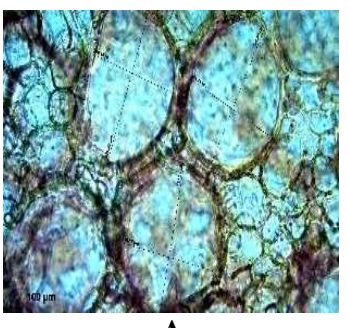

Day-45

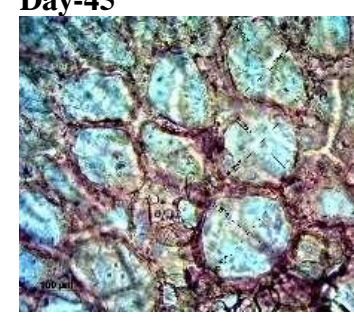

K

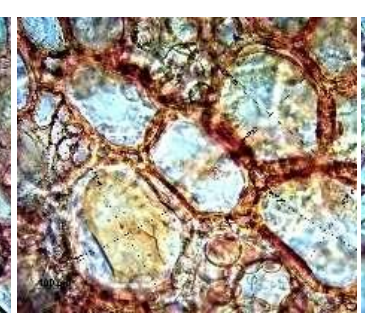

D

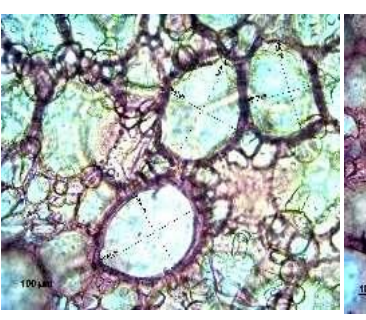

C

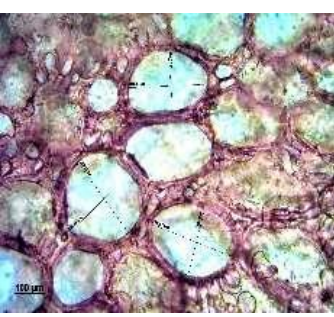

B

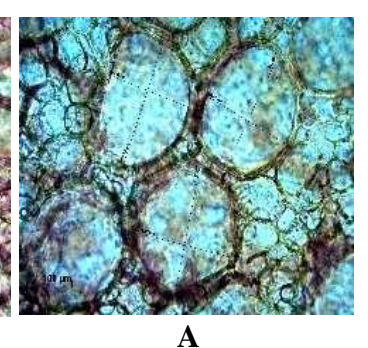

Figure 6. Thallus cross-section of Kappaphycus alvarezii. A. 2 Hours; B. 1.5 Hours; C. 1 Hour; D. 0.5 Hours; K. Control 
Based on the picture above, it can be observed that the seaweed cells are elongated oval in shape. The size of the cells increases towards the center of the thallus and decreases in size towards the edge of the thallus. These small cells are young cells that are newly formed and will enlarge according to the growth that occurs. In all treatments in this study, the cell diameter increased with increasing cultivation time. Form organs that have different structures and functions. The growth of seaweed thallus is a change in cell conditions and an increase in the size of seaweed cells. Hayashi et al. (2007) stated that the intensity of sunlight and its adequacy for seaweed determines the fulfillment of nutrients for seaweed growth.

\section{ACKNOWLEDGEMENTS}

Our gratitude goes to the Ministry of Education, Culture, Research and Technology, Republic Indonesia, who funded this research through the Doctoral Grant scheme for the 2021 fiscal year.

\section{REFFERENCES}

Aris M, Fatma M, Rusmawati L. 2021. Study of seaweed Kappaphycus alvarezii explants growth in the different salinity concentration. Jurnal Ilmiah Perikanan dan Kelautan 13 (1): 97-105. DOI: 10.20473/jipk.v13i1.19842. [Indonesian]

Basmal J, Muhamad LH, Rinta K, Nurhayati. 2019. Growth hormone, nitrogen and potassium content in the formulated solid waste from agar processing for fertilizer application. Squalen Bull Mar Fish Postharvest Biotechnol 14 (3): 131-139. DOI: 10.15578/squalen.v14i3.385.

Basmal J, Rinta K, Bagus SBU. 2015. Mutu SAP liquid rumput laut Sargassum yang diekstrak menggunakan kalium hidroksida sebagai bahan pupuk. Jurnal Pasca Panen dan Bioteknologi 10 (2): 143-153. DOI: 10.15578/jpbkp.v10i2.365. [Indonesian]

Cokrowati N, Diniarti N. 2019. Komponen Sargassum aquifolium sebagai hormon pemicu tumbuh untuk Eucheuma cottonii. Jurnal Biolog Tropis. Universitas Mataram Press, Mataram. DOI: 10.29303/jbt.v19i2.1107. [Indonesian]

Cole KM, Sheath RG. 1992. Biology of the Red Algae. Cambridge University Press, New York. DOI: 10.2216/i0031-8884-31-3-4-368.1.

Dawes CJ, Lluisma AO, Trono GC. 1994. Laboratory and field growth studies of commercial strains of Eucheuma denticulatum and Kappaphycus alvarezii in the Philippines. J Appl Phycol 6 (1): 21-24. DOI: $10.1007 / \mathrm{BF} 02185899$.

Dinas Kelautan dan Perikanan. 2020. Data produksi rumput laut Provinsi Nusa Teanggara Barat. DKP Provinsi Nusa Tenggara Barat. Mataram, Lombok, Nusa Tenggara Barat, Indonesia. [Indonesian]

Gao X, Xiangdong F. 2017. Hormone Metabolism and Signaling in Plants. Elsevier, New York, USA.

García IB, Ana KD, Ledezma AKD, Montano EM, Leyva JAS, Carrera E, Ruiz IO. 2020. Identification and quantification of plant growth regulators and antioxidant compounds in aqueous extracts of Padina durvillaei and Ulva lactuca. Agronomy 10 (6): 866. DOI: 10.3390/agronomy10060866.

Górka B, Wieczorek PP. 2017. Simultaneous determination of nine phytohormones in seaweed and algae extracts by HPLC-PDA. J Chromatograph B 1057: 32-39. DOI: 10.1016/j.jchromb.2017.04.048.

Harapan SBS, Retno AM, Mugi M. 2019. Performansi pertumbuhan rumput laut (Kappaphycus alvarezii) dengan menggunakan bibit hasil kultur dan non kultur jaringan di BBPBL Lampung. Jurnal Kelautan dan Perikanan Terapan 2 (2): 93-99. DOI: 10.15578/jkpt.v2i2.8075.

Hayashi L, de Paula EJ, Chow F. 2007. Growth rate and carrageenan anlyses in four strains of Kappaphycus alvarezii (Rhodophyta, Gigartinales) farmed in the subtropical waters of Sao Paulo State,
Brazil. J Appl Phycol 19 (5): 393-399. DOI: 10.1007/s10811-0069135-6.

Kasim M, Ahmad M. 2017. Comparison growth of Kappaphycus alvarezii (Rhodophyta, Solieriaceae) cultivation in floating cage and longline in Indonesia. Aquacult Rep 6: 49-55. DOI: 10.1016/j.aqrep.2017.03.004.

Khan W, Rayirath UP, Subramanian S, Jithesh MN, Rayorath P, Hodges DM, Critchley AT, Craigie JS, Norrie J, Prithiviraj B. 2009. Seaweed extract as biostimulants of plant growth and development. J Plant Growth Regul 28: 386-399. DOI: 10.1007/S00344-009-9103-X.

Khedia J, Dangariya M, Nakum AK, Agarwal P, Panda A, Parida AK, Agarwal PK. 2020. Sargassum seaweed extract enhances Macrophomina phaseolina resistance in tomato by regulating phytohormones and antioxidative activity. J Appl Phycol 32 (6): 4373-4384. DOI: 10.1007/s10811-020-02263-5.

Kiseleva AA, Tarachovskaya ER, Shishova MF. 2012. Biosynthesis of phytohormones in algae. Russ J Plant Physiol 59 (5): 595-610. DOI: 10.1134/S1021443712050081.

Liu J, Sibusiso L, Qifang W, Mingjiang W, Jong-il C, Haibin T. 2020. Review article: Pharmaceutical and nutraceutical potential applications of Sargassum fulvellum. BioMed Res Intl. DOI: $10.1155 / 2020 / 2417410$.

Mageswaran R, Sivasubramaniam S. 1984. Mineral and protein contents of some marine algae from the coastal areas of Northern Sri Lanka. J Nat Sci Found Sri Lanka 12 (2): 179-189. DOI: 10.4038/jnsfsr.v12i2.8356.

Mahmoud SH, Salama DM, El-Tanahy AMM, El-Samad EHA. 2019. Utilization of seaweed (Sargassum vulgare) extract to enhance growth, yield and nutritional quality of red radish plants. Ann Agric Sci 64 (2): 167-175. DOI: 10.1016/j.aoas.2019.11.002.

Marimuthu J, Essakimuthu P, Narayanan J, Anantham B, Tharmaraj RJJM, Arumugam S. 2012. Phytochemical characterization of brown seaweed Sargassum wightii. Asian Pac J Trop Dis S109-S113. DOI: 10.1016/S2222-1808(12)60134-0.

Maulani RK, Marlina A, Gunarto L. 2017. Karakteristik jaringan secara histologi dari strain rumput laut (Kappaphycus alvarezii) yang terinfeksi penyakit ice-ice. Torani J Fish Mar Sci 1 (1): 45-57. DOI: 10.35911/torani.v1i1.3796. [Indonesian]

Nadlir A, Titik S, Kurnia A, Dicky H, Seto W, Alfabetian HC, Haditomo. 2019. Production performance of Gracilaria verrucosa using verticulture method with various wide planting area in Karimunjawa. Omni-Akuatika 15 (1): 47-58. DOI: 10.20884/1.oa.2019.15.1.671.

Nursidi, Syamsu AA, Hilal A, dan Akbar MT. 2017. Environmental parameters and specific growth of Kappaphycus alvarezii in Saugi Island, South Sulawesi Province, Indonesia. AACL Bioflux 10 (4): 698-702.

Pacholczak A, Nowakowska K, Stefan P. 2016. The effects of synthetic auxin and a Seaweed-based biostimulator on physiological aspects of Rhizogenesis in ninebark stem cuttings. Notulae Botanicae Horti $\begin{array}{llll}\text { Agrobotanici } & \text { Cluj-Napoca } 44 & \text { (1): 85-91. DOI: }\end{array}$ 10.15835/nbha44110061.

Panda D, Pramanik K, Nayak BR. 2012. Use of seaweed extracts as plant growth regulators for sustainable agriculture. Intl J Bio-resour Stress Manag 3 (3): 404-411.

Risjani Y, Abidin G. 2020. Genetic diversity and similarity between green and brown morphotypes of Kappaphycus alvarezii using RAPD. J Appl Phycol 32 (4): 2253-2260. DOI: 10.1007/s10811-020-02223-z.

Rochester WA, Skewes TD, Suadnya IW, Butler JRA, Lyne VD, Handayani T, Habibi P, Karnan, Cokrowati N. 2016. A typology of natural resource use for livelihood impact assessments in Nusa Tenggara Barat Province, Indonesia. Clim Risk Manag 12: 59-68. DOI: $10.1016 /$ j.crm.2015.11.002.

Sasikala M, Indumathi E, Radhika S, Sasireka R. 2016. Effect of seaweed extract (Sargassum tenerrimum) on seed germination and growth of tomato plant. Intl J ChemTech Res 9 (9): 285-293.

Simatupang NF, Pong-Masak PR, Ratnawati P, Agusman, Paul NA, Rimmer MA. 2021. Growth and product quality of the seaweed Kappaphycus alvarezii from different farming locations in Indonesia. Aquacult Rep 20: 100685. DOI: 10.1016/j.aqrep.2021.100685.

Tri PH. 2002. Morphological variability of Kappaphycus cottonii in Vietnam. In: Abbott IA, McDermid K (eds.). Taxonomy of Economic Seaweeds with Reference to Some Pacific Species. Volume VIII. California Sea Grant College Program, University of Calfornia, San Diego, USA.

Wouthuyzen S, Herandarudewi SMC, Komatsu T. 2016. Stock assesment of brown seaweeds (Phaeophyceae) along the Bitung-Bentena Coast, 
North Sulawesi Province, Indonesia for alginate product using satellite remote sensing. Proc Environ Sci 33: 553-561. DOI 10.1016/j.proenv.2016.03.107.

Xiao X, Agusti S, Lin F, Xu C, Yu Y, Pan Y, Li K, Wu J, Duarte CM. 2019. Resource (light and nitrogen) and density-dependence of seaweed growth. Front Mar Sci 6: 618. DOI: 10.3389/fmars.2019.00618
Yu Z, Song M, Pei H, Jiang L, Hou Q, Nie C, Zhang L. 2017. The effects of combined agricultural phytohormones on the growth, carbon partitioning and cell morphology of two screened algae. Bioresour Technol 239: 87-96. DOI: 10.1016/j.biortech.2017.04.120.

Zwack PJ, Rashotte AM. 2013. Cytokinin inhibition of leaf senescence. Plant Signal Behav 8 (7): 1-7. DOI: 10.4161/psb.24737. 